\title{
Change in Air Pollution and Human Mobility Trends during COVID-19 Lockdown Measures in Turkey
}

\author{
(1) Caner Baysan, ${ }^{1}$ (D) Seher Palanbek Yavaş, ${ }^{2}$ (D) Meltem Çöl ${ }^{1}$ \\ 'Department of Public Health, Epidemiology, Ankara University Faculty of Medicine, Ankara, Turkey \\ ${ }^{2}$ Department of Public Health, Environmental Health, Istanbul University Faculty of Medicine, Istanbul, Turkey
}

\section{ABSTRACT}

Objectives: This study aimed to examine the change in the air quality parameters of 31 cities that were affected by the strict measures taken in Turkey during the months of March, April, and May and their relationship with the activity parameters.

Methods: Thirty-one cities included in this study were assessed in terms of their average particulate matter $\left(\mathrm{PM}_{10}\right)$, sulfur dioxide $\left(\mathrm{SO}_{2}\right)$, carbon monoxide $(\mathrm{CO})$, nitrogen dioxide $\left(\mathrm{NO}_{2}\right)$, and ozone $\left(\mathrm{O}_{3}\right)$ values in the months of March, April, and May between 2017 and 2020 and their activity data in the same months of 2020, which had six different subdimensions.

Results: When the compared the 3-month average air parameters of the cities and the 3-month average parameters of the previous 3 years, the $\mathrm{PM}_{10}$ and $\mathrm{NO}_{2}$ levels decreased from $47.6 \mu \mathrm{g} / \mathrm{m}^{3}$ to $38.1 \mu \mathrm{g} / \mathrm{m}^{3}$ and from 54.8 $\mu \mathrm{g} / \mathrm{m}^{3}$ to $25.7 \mu \mathrm{g} / \mathrm{m}^{3}$, respectively $(\mathrm{p}=0.001$ and $\mathrm{p}=0.001)$. When the change in the air quality parameter and the activity change correlation were evaluated, a statistically significant correlation regarding "retail and recreation," "workplaces," and "residential," which were the three subdimensions of the $\mathrm{SO}_{2}$ change activity was determined $(p=0.034, p=0.002$, and $p=0.003$, respectively). In the linear regression models established, it was determined that "workplaces" had a statistically significant relationship regarding $\mathrm{SO}_{2}$ change $(r=0.339, p=0.038)$.

Conclusion: The decrease in air pollution that is an indirect positive effect of the pandemic on the environment is temporary, but governments should learn from this lockdown on how to reduce pollution on a longterm basis.

Address for correspondence: Dr. Seher Palanbek Yavaş. Department of Public Health, Environmental Health, Istanbul University Faculty of Medicine, Istanbul, Turkey

Phone: +90 5546797768

E-mail:

spalanbekyavas@gmail.com

Received Date: 26.01.2021

Accepted Date: 02.02.2021

Published online: 20.08.2021

OCopyright 2021 by Anatolian Journal of Family Medicine -

Available online at www.anatoljfm.org

OPEN ACCESS

Keywords: Air pollution, COVID-19, particulate matter, nitrogen dioxide, sulfur dioxide

\section{INTRODUCTION}

At the end of December 2019, a viral pneumonia of unknown origin was identified in the city of Wuhan, located in the Hubei region of China. ${ }^{[1]}$ The International Committee on Taxonomy of Viruses identified the virus causing viral pneumonia on February 11 and announced the name of the virus, "severe acute respiratory syndrome coronavirus 2." At the same time, World Health Organization (WHO) has announced the name of this new disease as "COVID-19."[2] This disease that rapidly spreads was first seen in Thailand after China and then has spread almost all over the world. ${ }^{[3]}$ In a 9-month period, as of September 15, the total number of confirmed cases in the world ( 216 countries and regions) was 29.634.637, and the case fatality rate had reached to $936.282 .{ }^{[4]}$ It has been stated that in Turkey, on March 11, 2020, the first notified case was a man. Six days after the notification of the first 
case, on March 17, the first case of death due to COVID-19 in Turkey was an 89-year-old male patient. From the day of the notification of the first case to September 15, there had been 294.620 cases and 7.186 deaths. ${ }^{[5,6]}$ Within this period of time, countries have taken various types of measures to prevent the spread of the pandemic, such as shutting down schools and businesses, imposing travel bans and curfews, and making social distancing and wearing of masks obligatory. ${ }^{[7]}$ During the restriction period, shutting down schools and stores, except for those that provide essential services; suspending the operations in factories; and having their employees work either remotely or by turns have bound the population to their homes. The changes that were observed in Turkey during the restriction period are shown in Table 1..$^{[6-13]}$

Therefore, studies have found a decrease in the vehicle traffic on the roads and, correspondingly, a decrease in the air pollutant emission, in the emissions originating from industrial activities, that is, the decrease in the levels of ambient anthropogenic pollutants. ${ }^{[14-16]}$ Although the restriction periods were implemented for the purpose of protecting people from the disease, it may have had a positive effect such as the decrease in air pollution. ${ }^{[15-17]}$ The WHO has identified air pollution as a major problem that severely threatens human health and has indicated that 9 out of 10 people on Earth live where air pollution concentrations are high. ${ }^{[18]}$ When 51 cities that had sufficient data in the report issued in Turkey for this year were evaluated, it was determined that $98 \%$ of particulate matter $\left(\mathrm{PM}_{10}\right)$ measurements exceeded the annual limit value $\left(20 \mu \mathrm{g} / \mathrm{m}^{3}\right)$ determined by the $\mathrm{WHO}$, and when they were evaluated in accordance with the national limits, it was determined that $70 \%$ of the cities have exceeded the limit value $\left(40 \mu \mathrm{g} / \mathrm{m}^{3}\right)$. ${ }^{[19]}$ According to another report that was issued last year, the atmosphere in Turkey was more polluted in terms of PM than that in Europe. This pollution, in 2019, was 31.0\%

Table 1. Measures taken in Turkey during the pandemic

\section{Date}

Feb 05, 2020

Feb 29, 2020 precaution.

March 16, 2020

March 19, 2020

March 20, 2020

March 22, 2020

March 27, 2020

March 28, 2020

Apr 01, 2020

Apr 03, 2020

Apr 04, 2020

Apr 11-12, 2020

Apr 18-19, 2020

Apr 23-26, 2020

May 1-3, 2020

May 8-10, 2020

May 15-19, 2020

May 22-26, 2020

May 31, 2020

June 01, 2020

June 09, 2020

\section{Restrictive measures}

All flights from China were suspended.

All round-trip flights between Turkey and Italy, Turkey and South Korea, and Turkey and Iraq were suspended as

Education in elementary and secondary schools and universities was suspended. It was announced that all sports contests and leagues were suspended indefinitely.

All kinds of national- and international-scale scientific, cultural, artistic, and similar gatherings and activities to be conducted outdoors or indoors were suspended.

Citizens aged $\geq 65$ years and those with chronic illnesses became subjected to curfew. State institutions and organizations were allowed to work by turns and remotely.

Foreign flights were completely suspended.

Intercity travels were banned except for individuals who obtained permission from the governorates due to their justifications.

Citizens aged $\leq 20$ years became subjected to curfew.

All entrances to and exits from 30 cities with metropolitan status and Zonguldak by land, air, or sea were suspended.

Turkish Air Lines and domestic flights were suspended.

Curfew was declared for the weekend (30 metropolitans and Zonguldak).

Curfew was declared for the weekend. (30 metropolitans and Zonguldak).

Curfew was declared. (30 metropolitans and Zonguldak).

Curfew was declared (30 metropolitans and Zonguldak).

Curfew was declared for the weekend (15 cities).

Curfew was declared (15 cities).

Curfew was declared (81 cities).

The travel bans on 15 cities had been lifted.

It had been decided that places such as entertainment centers, cafes, restaurants, recreation areas, which were shut down, would reopen within the frame of determined rules.

The restriction on citizens aged $\geq 65$ years had been lifted on the condition that they would go outside on weekdays between the hours of 10:00 a.m. and 20:00 p.m., and on minors ( $<18$ years of age), restrictions had been lifted on the condition that they would be accompanied by a parent. 
more than that in Europe. Furthermore, in the same report, it was stated that the sulfur dioxide $\left(\mathrm{SO}_{2}\right)$, nitrogen dioxide $\left(\mathrm{NO}_{2}\right)$, ozone $\left(\mathrm{O}_{3}\right)$, and carbon monoxide (CO) values of several cities were significantly higher than the limit values of the WHO. ${ }^{[20]}$

This study aimed to determine the change in ambient air pollutants during the restriction period in Turkey and examine its relationship with the mobility trend.

\section{METHOD}

Area of the Study: Turkey is a transcontinental Eurasian country. Asian Turkey includes $97 \%$ of the country, and European Turkey comprises 3\% of the country's territory. The territory of Turkey is more than $1,600 \mathrm{~km}$ (990 mi) long and $800 \mathrm{~km}$ (500 mi) wide, with a roughly rectangular shape. It lies between latitudes $36^{\circ}$ and $42^{\circ} \mathrm{N}$ and longitudes $26^{\circ}$ and $45^{\circ} E^{[21,22]}$ In Turkey, there are 81 cities in total. The cities with a population that exceeds 750.000 are referred to as metropolis. According to this, in Turkey, there are $30(96.8 \%)$ metropolises in total. ${ }^{[23]}$ The restrictions implemented to control the spread of the COVID-19 pandemic have intensely involved these 30 cities and Zonguldak (Zonguldak has an iron and steel factories therefore, air pollution is more common in this province). ${ }^{[8-10]}$ Therefore, these 31 cities were designated as study areas.

Dependent Variable: The $\mathrm{PM}_{10^{\prime}} \mathrm{SO}_{2^{\prime}} \mathrm{CO}, \mathrm{NO}_{2^{\prime}}$ and $\mathrm{O}_{3}$ values of these 31 cities between 2017 and 2020 (4 years) measured in the months of March, April, and May were considered as dependent variables.

Air Quality Data: The Environmental Impact Assessment of the Ministry of Environment and Urban Planning and the Air Quality Bulletin by the Directorate General of Permit and Inspection are issued regularly on a monthly basis. In the report, the monthly average values of the air measuring stations located in the cities (multiple) are provided. In our study, the air quality data was created based on the "Air Quality Bulletin" reports published. ${ }^{[24]}$ By way of estimating the average values of multiple air measuring stations for each city, the air quality parameter belonging to that particular city was estimated. The average $\mathrm{PM}_{10}, \mathrm{SO}_{2}, \mathrm{CO}, \mathrm{NO}_{2}$ and $\mathrm{O}_{3}$ parameters of the cities included in the study, measured in the months of March, April, and May in 2017-2020, were included in the scope of the assessment. By means of taking the average of the parameters for each month within 2017-2019, the monthly values representing the previous three years were estimated. Moreover, by estimating the average values of the measurement values of March, April, and May, the values representing the 3-month average values were obtained.

Independent Variable: The daily activity data of 31 cities during the months of March, April, and May were considered as independent variables.

Human Mobility Trends: In this study, Google's "Community Mobility Reports" were used. The mobility report of Google consists of the data of the users who allow Google to use their location. The mobility report offers the daily relative mobility change (based of the reference day) percentages resulting from the COVID-19 pandemic based on the cities in Turkey. The reference day was the median value belonging to the 5 -week period between January 3 and February 6, 2020 and represented the normal value for that day of the week. The mobility change offers the relative change percentages of six different parameters in the assessment. Six parameters such as retail and recreation points, markets and pharmacies, parks, public transport stations, workplaces and homes were used for mobility change. ${ }^{[13]}$

Statistical Analysis: For the statistical analyses of the research data, Statistical Package for the Social Sciences (SPSS), and for Windows, version 25.0 (SPSS Inc. Chicago, USA) computer packaged software was used. Descriptive data included the mean, standard deviation, median, and 25 percentile- 75 percentile ( $25 p-75 p)$. The normality distribution compatibility was evaluated using analytical (Kolmogorov-Smirnov test) and visual (histogram and probability graphics) methods. In dependent variables that did not comply with the normal distribution, the double-metric assessment was conducted using the Wilcoxon test, and those that complied with the normal distribution were evaluated in the dependent groups using the Paired t-test. In addition, Pearson correlation test was used for normally distributed continuous variables and Spearman correlation test was used for abnormally distributed variables. Correlation coefficients $(r)$ were evaluated as follows: 0.0-0.19, "very weak"; 0.20-0.39, "weak"; 0.40-0.59, "moderate"; 0.60-0.79, "strong"; and 0.80-1.00, "very strong." With variables that appeared statistically significant according to the correlation analysis, the linear regression model was established. The logarithm of the variables that did not comply with the normal distribution was taken. The linear regression model was established using the bacward-LR method. Significant level was considered $p<0.05$.

\section{RESULTS}

The status regarding the change of five air quality parameters of 31 cities in Turkey between 2020 and the previous 3 years $(2019,2018$, and 2017) was evaluated.

When $\mathrm{PM}_{10}$ measurements were evaluated based on March, April, and May monthly average values, it was deter- 
mined that the values in 2020 had significantly decreased compared with the average values in the previous 3 years $(p=0.002, p=0.001$, and $p=0.006)$. The $C O$ measurement value had significantly decreased in March 2020 compared with the average values in the same month of the previous 3 years $(p=0.035)$. The $\mathrm{NO}_{2}$ measurement values had significantly decreased in March, April, and May of 2020 compared with the average values in the same months of the previous 3 years $(p=0.007, p=0.001$, and $p=0.001)$. The change of air quality parameters according to months of pre-COVID-19 and COVID-19 periods is summarized in Table 2 .

When the cities are evaluated according to the 3-month average of the air parameter changes, in 2020 all values of the five air quality parameters were lower than the average values of the previous 3 years. Out of these parameters, it was determined that the 3-month average values of $\mathrm{PM}_{10}$ and $\mathrm{NO}_{2}$ in 2020 had significantly decreased compared with the 3-month average values in the previous three years $(p=0.001)$. The change of air quality parameters in the pre-COVID-19 and COVID-19 periods based on 3-month is summarized in Table 3.

When the mobility data by months were evaluated, it was determined that the mobility data, excluding residence mobility data, decreased compared with the baseline. When the 3-month period is evaluated, the highest decrease was found in the "transit stations" data in March, and pursuant to the baseline, it was $67.8 \%$. The minimum decrease, on the other hand, was found in the "grocery and pharmacy"
Table 3. Change of air quality parameters in the preCOVID-19 and COVID-19 periods based on 3-month

\begin{tabular}{cccc} 
& Measurements & Change (\%) & p \\
\hline $\mathrm{PM}_{10}\left(\mu \mathrm{g} / \mathrm{m}^{3}\right)$ & & & \\
COVID-19 & $38.1 \pm 11.0$ & -19.8 & $0.001^{*}$ \\
Pre-COVID-19 & $47.6 \pm 13.8$ & & \\
$\mathrm{SO}_{2}\left(\mu \mathrm{g} / \mathrm{m}^{3}\right)$ & & & \\
COVID-19 & $7.6(5.2-128.0)$ & -1.6 & $0.358^{\dagger}$ \\
Pre-COVID-19 & $9.2(7.2-13.2)$ & & \\
$\mathrm{CO}\left(\mu \mathrm{g} / \mathrm{m}^{3}\right)$ & & & \\
$\mathrm{COVID}-19$ & $588.8(436.4-1102.7)$ & -20.2 & $0.102^{\dagger}$ \\
Pre-COVID-19 & $852.1(560.1-1043.8)$ & & \\
$\mathrm{NO}{ }_{2}\left(\mu \mathrm{g} / \mathrm{m}^{3}\right)$ & & & \\
COVID-19 & $21.8(16.9-33.2)$ & -53.1 & \\
Pre-COVID-19 & $38.8(29.6-50.0)$ & & \\
$\mathrm{O}_{3}\left(\mu \mathrm{g} / \mathrm{m}^{3}\right)$ & & & \\
COVID-19 & $44.3(36.7-58.3)$ & -4.3 & $0.975^{\dagger}$ \\
Pre-COVID-19 & $47.0(33.1-53.4)$ & &
\end{tabular}

Pre-COVID-19 period includes the 2017, 2018 and. 2019. COVID-19 period includes the 2020.

CO: Carbon monoxide; $\mathrm{NO}_{2}$ : Nitrogen dioxide; $\mathrm{O}_{3}$ : Ozone; $\mathrm{PM}_{10}$ : Particulate matter; $\mathrm{SO}_{2}$ : Sulfur dioxide.

Data are presented as mean \pm SD and median (25p-75p).

"Paired t-test, 'Wilcoxon Test.

data in March, and it was $5.8 \%$. The maximum increase was in the "residential" data in April, and it was 21.2\%. The relationship between air quality parameters and mobility

Table 2. Change of air quality parameters according to months of pre-COVID-19 and COVID-19 periods

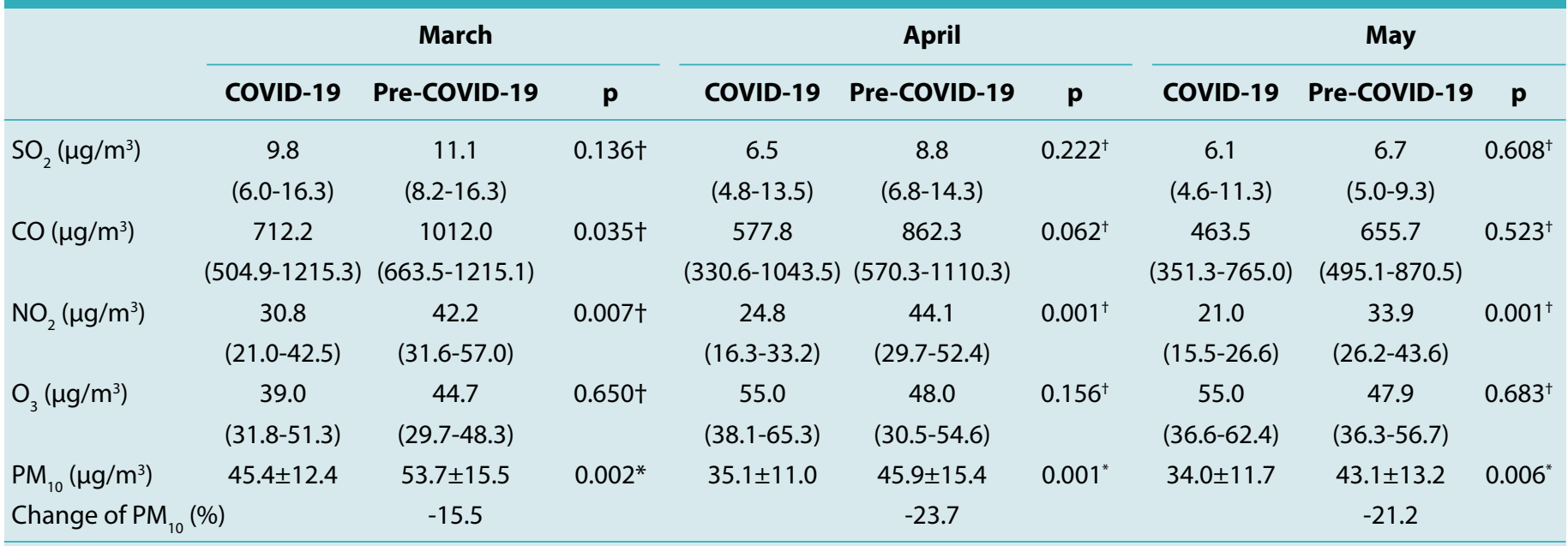

Pre-COVID-19 period includes the 2017, 2018 and. 2019. COVID-19 period includes the 2020.

CO: Carbon monoxide; $\mathrm{NO}_{2}$ : Nitrogen dioxide; $\mathrm{O}_{3}$ : Ozone; $\mathrm{PM}_{10}$ : Particulate matter; $\mathrm{SO}_{2}$ : Sulfur dioxide.

Data are presented as median (25p-75p) and mean \pm SD.

"Paired t test; ${ }^{+W i l c o x o n}$ test. 
change in 3 months are summarized in Table 4.

The linear regression models of $\mathrm{SO}_{2}$ change with mobility variables are summarized Table 5. Model 2 explains 33.9\% of the change in $\mathrm{SO}_{2}$. To formulate Model 2, the following was used:

$\mathrm{SO}_{2}$ change $(\%)=372.027+(-85.625) *(\operatorname{Ln}($ residential change $(\%)))+(3.99)^{*}($ workplaces change $(\%))$.

\section{DISCUSSION}

The rapid spread of the COVID-19 pandemic from China to other countries obliged countries to take protective measures. Countries, by taking measures such as imposing travel bans and closing the borders, have ensured that people stay in their homes and aimed to reduce the spread of the virus and, thus, the burden of the health effects. In Turkey, there had been an unprecedented restriction period as well. After the appearance of the first case toward the middle of March, to control the outbreak, the government had restricted the domestic and foreign travels, working in shifts by taking turns had started, and the industrial activities were suspended. Turkey, according to domestic and foreign reports issued, can be described as a country that shows effort to better its air quality, but the air pol- lution parameters remain above the limit values (WHO limit values). ${ }^{[19,20,25]}$ These changes that had occurred with regard to human mobility have caused a relative decrease in the anthropogenic influence in air pollution. Our study had focused on determining how air pollutant values have changed as a result of the restriction period. This unexpected effect of the pandemic has, in a way, enabled us to test the influence of the travel bans on air pollution.

In this study, the $\mathrm{PM}_{10}$ values measured in April, May, and June of the previous 3 years (2016-2019) were compared with those in the same months of 2020 (lockdown period: April, May, and June), and a statistically significant difference was found. PM are mixtures that consist of physical and chemical components that change depending on the region and are classified among the primary air pollutants. They are released into the atmosphere through industrial activities, transportation (road traffic), road dust, sea spray, and windblown soil. ${ }^{[26]}$ They contain carbon, organic components, metals, metal oxides, and ions in their composition. Similar to our study, when the PM levels of Turkey (for five metropolises such as, Istanbul, Izmir, Ankara, Bursa, and Adana) between 2018 and 2019 (March, April, May, and June) were compared with those in same

Table 4. Relationship between air quality parameters and mobility change in 3 months

\begin{tabular}{|c|c|c|c|c|c|}
\hline \multirow[t]{2}{*}{ Mobility change (\%) } & \multicolumn{5}{|c|}{ Change (\%) } \\
\hline & $\mathrm{PM}_{10}$ & $\mathrm{SO}_{2}$ & CO & $\mathrm{NO}_{2}$ & $\mathrm{O}_{3}$ \\
\hline \multicolumn{6}{|l|}{ Retail and recreation } \\
\hline $\mathrm{r}$ & -0.257 & 0.395 & -0.120 & -0.053 & -0.376 \\
\hline $\mathrm{p}$ & $0.179^{*}$ & $0.034^{\dagger}$ & $0.646^{+}$ & $0.836^{+}$ & $0.185^{\dagger}$ \\
\hline \multicolumn{6}{|l|}{ Grocery and pharmacy } \\
\hline$r$ & -0.300 & 0.137 & -0.382 & 0.018 & -0.284 \\
\hline $\mathrm{p}$ & $0.114^{*}$ & $0.479^{+}$ & $0.130^{+}$ & $0.945^{+}$ & $0.326^{+}$ \\
\hline \multicolumn{6}{|l|}{ Parks } \\
\hline$r$ & 0.092 & 0.303 & -0.243 & -0.106 & 0.191 \\
\hline$p$ & $0.636^{*}$ & $0.110^{+}$ & $0.348^{\dagger}$ & $0.675^{\dagger}$ & $0.513^{+}$ \\
\hline \multicolumn{6}{|l|}{ Transit station } \\
\hline $\mathrm{r}$ & 0.369 & 0.137 & 0.108 & 0.032 & 0.305 \\
\hline $\mathrm{p}$ & $0.049^{*}$ & $0.477^{\dagger}$ & $0.680^{+}$ & $0.900^{+}$ & $0.288^{+}$ \\
\hline \multicolumn{6}{|l|}{ Workplaces } \\
\hline$r$ & -0.149 & 0.555 & -0.123 & -0.001 & -0.305 \\
\hline$p$ & $0.440^{*}$ & $0.002^{+}$ & $0.639^{\dagger}$ & $0.997^{\dagger}$ & $0.288^{+}$ \\
\hline \multicolumn{6}{|l|}{ Residential } \\
\hline$r$ & -0.114 & -0.525 & 0.230 & -0.088 & -0.266 \\
\hline$p$ & $0.555^{*}$ & $0.003^{+}$ & $0.374^{+}$ & $0.729^{+}$ & $0.358^{+}$ \\
\hline
\end{tabular}

CO: Carbon monoxide; $\mathrm{NO}_{2}$ : Nitrogen dioxide; $\mathrm{O}_{3}$ : Ozone; $\mathrm{PM}_{10}$ : Particulate matter; $\mathrm{SO}_{2}$ : Sulfur dioxide.

"Spearman's correlation test; ${ }^{\dagger}$ Pearson correlation test. 
Table 5. The linear regression models of $\mathrm{SO}_{2}$ change with mobility variables

\begin{tabular}{|c|c|c|c|c|c|c|c|c|}
\hline & B & Standart error & Standardized coefficients & $\mathbf{t}$ & $\mathbf{p}$ & \multicolumn{2}{|c|}{$95 \% \mathrm{Cl}$} & Adjusted R \\
\hline Constant & 317.503 & 203.735 & & 1.558 & 0.132 & -102.097 & 737.104 & 0.317 \\
\hline Parks & 0.436 & 1.060 & 0.094 & 0.411 & 0.684 & -1.747 & 2.619 & \\
\hline Workplaces & 4.072 & 1.869 & 0.441 & 2.179 & 0.039 & 0.223 & 7.922 & \\
\hline \multicolumn{9}{|l|}{ MODEL 2} \\
\hline Constant & 372.027 & 152.197 & & 2.444 & 0.022 & 59.182 & 684.872 & 0.339 \\
\hline Workplaces & 3.990 & 1.829 & 0.432 & 2.182 & 0.038 & 0.232 & 7.749 & \\
\hline Ln (Residential) & -85.625 & 67.843 & -0.250 & -1.262 & 0.218 & -225.078 & 53.828 & \\
\hline
\end{tabular}

months of 2020, which was the restriction period, it was determined that the PM level that decreased in March, with the removal of restrictive measures, had started to increase in June. ${ }^{[19]}$ In a study conducted in Milan, it was indicated that the $\mathrm{PM}_{10}$ values of the restriction period, in zones divided based on the population density, had decreased at the rate of $32.7 \%$ and $40.5 \%$ compared with those during the normal period, and this decrease maybe linked to the decrease in traffic emissions. In the same study, when the partial lockdown period was compared with the total lockdown period, it was found that the $\mathrm{PM}_{10}$ values were $13.1 \%-18.9 \%$ less, and this decrease maybe caused by the restrictions on the industrial activities. ${ }^{[27]}$ According to the State of Global Air Report 2019, China is the leading country where the air pollution levels and death rates linked to this (1.2 million) are observed the most. ${ }^{[28]}$ In a study that investigated the change in the air quality in Northern China during the restriction period and its relation to mobility, it was determined that with government prohibitions, human mobility decreased at the rate of $69.85 \%$, and consequently, there had been a $7.80 \%$ improvement in the air quality index, and the $\mathrm{PM}_{10}$ level decreased at the rate of $13.66 \%$. ${ }^{[2]}$

In this study, it was determined that the $\mathrm{NO}_{2}$ measurement values were significantly low in the months of March, April, and May of 2020 compared with those in the same months of the previous 3 years. Similar to our study, in a study conducted in Wuhan, China, where the pandemic has started, it was found that the $\mathrm{PM}_{10}$ level had decreased to $40.2 \%$ compared with that during the period before restrictions and among the air pollutants, the $\mathrm{NO}_{2}$ level had the most significant decrease (53.3\%). ${ }^{[30]}$ In the study conducted in Singapore, it was determined that during the period of strict restrictions, the $\mathrm{PM}_{10}$ and $\mathrm{NO}_{2}$ levels had decreased at the rate of $23 \%$ and $54 \%$, respectively; however, no relation between the $\mathrm{PM}_{10}$ levels and the human mobility trend was found. ${ }^{[14]}$ In the study conducted in Sale, Morocco, on the other hand, it was determined that throughout the restriction period, the PM10 level had decreased at the rate of 96\% (from 114.6 to $28.3 \mu \mathrm{g} / \mathrm{m}^{3}$ ) and the $\mathrm{NO}_{2}$ level had decreased at the rate of $75 \%$ (from 5.6 to $0.2 \mu \mathrm{g} / \mathrm{m}^{3}$ ). Although the decrease in the $\mathrm{NO}_{2}$ levels was due to the decrease in industrial and traffic activities in particular, the decrease in the $\mathrm{PM}_{10}$ level was due to the land and sea/port traffic. ${ }^{[31]}$

When the community mobility data was evaluated in this study, the largest decrease had occurred regarding the transit stations in March, and in April, residential change had increased $21.2 \%$, more than those in the other months. Moreover, a positive and weak correlation was noted between the change in $\mathrm{PM}_{10}$ and the change in transit stations. Similarly, in a study conducted in Ontario, Canada, while the time spent at home had increased at the rate of $28 \%$ during the state of emergency (SOE), according to Google's Community Mobility Reports, retail and recreation, grocery and pharmacy, parks, transit stations, and workplaces had decreased at indicated rates. Correspondingly, it was determined that the $\mathrm{NO}_{2}$ and $\mathrm{NO}_{x}$ levels during the SOE period had decreased by $2 \mathrm{ppb}^{[32]}$ In the study conducted via the Sentinel-5P satellite data 
in Mumbai and Delhi in India, which is one of the countries that constantly struggles with its air quality, it was determined that during the lockdown period, there had been a $40 \%-50 \%$ decrease in the $\mathrm{NO}_{2}$ levels in both cities compared with those during the same period of the previous year. ${ }^{[33]}$

In this study, a significant decrease in the $\mathrm{SO}_{2}$ levels was not found. However, the linear regression conducted between the change in workplaces and the change in $\mathrm{SO}_{2}$ was determined to be statistically significant. The reason behind this shared change maybe the closing of businesses and the reduction of production in factories and power plants. Similarly, in a report issued in our country, it was determined that as a result of the partial shutdown of thermal power plants in the cities of Kahramanmaras, Sivas, Zonguldak, Kutahya, and Karabuk due to incompliance with the Environmental Law and the COVID-19 pandemic, the data obtained from the satellite images showed a sharp drop in the $\mathrm{SO}_{2}$ levels. ${ }^{[19]}$ Similarly, in a study conducted in Wuhan, it was determined that there had been a $3.9 \%$ decrease in the $\mathrm{SO}_{2}$ level. ${ }^{[30]}$ In the study conducted in Singapore, it was found that there had been a sharp decrease of $52 \%$ in the $\mathrm{SO}_{2}$ level and a positive correlation was noted with the residential places, which is among the human mobility data, while a negative correlation was noted with other mobility data (car park, driving, transit stations, workplaces). ${ }^{[14]}$

The study used data from individuals that allowed location data to be shared on Google. This data may not fully reflect the movement data of the community. This is a limitation of the study. Another limitation of the study is that the weather conditions (temperature, humidity, wind, etc.), which are closely related to daily air pollutant levels, were not examined in the study.

\section{CONCLUSION}

In this study, it shows that that $\mathrm{PM}_{10}$ and $\mathrm{NO}_{2}$ values decreased significantly during the restriction period due to the COVID-19 pandemic regarding air quality in 31 metropolises of Turkey covered by the study. Additionally, the decrease in the $\mathrm{PM}_{10}$ levels was significantly linked to the downward tendency in the human mobility data. Air pollution is a complex problem that is related to several factors. The decrease in air pollution that is an indirect positive effect of the pandemic on the environment is temporary, but governments should learn from this lockdown on how to reduce pollution on a long-term basis.

\section{Disclosures}

Peer-review: Externally peer-reviewed.

Conflict of Interest: None declared.
Funding: The authors received no specific funding for this work.

Ethics Committee Approval: This study was approved by the Ankara University Research Ethics Committee (Approval date: Nov 30, 2020, and Approval number: 267).

Authorship Contributions: Concept - C.B., S.P.Y., M.Ç.; Design - C.B., S.P.Y., M.Ç.; Supervision - C.B., S.P.Y., M.Ç.; Materials - C.B., S.P.Y., M.Ç.; Data collection \&/or processing - C.B., S.P.Y.; Analysis and/or interpretation - C.B., S.P.Y.; Literature search - C.B., S.P.Y.; Writing - C.B., S.P.Y.; Critical review - C.B., S.P.Y., M.Ç.

\section{REFERENCES}

1. Li Q, Guan X, Wu P, Wang X, Zhou L, Tong Y et al. Early transmission dynamics in Wuhan, China, of novel coronavirus infected pneumonia. N Engl J Med 2020;382(13):1199-207.

2. WHO. Naming the coronavirus disease (COVID-19) and the virus that causes it. Available at: https://www.who.int/emergencies/diseases/novel-coronavirus-2019/technical-guidance/ naming-the-coronavirus-disease-(covid-2019)-and-the-virusthat-causes-it. Accessed Sep 18, 2020.

3. Lai CC, Wang CY, Wang YH, Hsueh SC, Ko WC, Hsueh PR. Global epidemiology of coronavirus disease 2019 (COVID-19): disease incidence, daily cumulative index, mortality, and their association with country healthcare resources and economic status. Int J Antimicrob Agents 2020;55(4):105946. [CrossRef]

4. Worldometer. COVID-19 coronavirus pandemic, coronovirus cases. Available at: https://www.worldometers.info/ coronavirus/?zarsrc=130. Accessed Sep 15, 2020.

5. Republic of Turkey Ministry of Health. COVID-19 information page. Available at: https://covid19.saglik.gov.tr/TR-66935/ genel-koronavirus-tablosu.html. Accessed Sep 20, 2020.

6. Türkiye Sağlık Politikaları Enstitüsü. COVID-19 pandemi yönetiminde Türkiye örneği: sağlık politikası uygulamaları ve stratejileri. Available at: https://www.tuseb.gov.tr/tuspe/uploads/ yayinlar/makaleler/pdf/21-08-2020__5f3f6e1402cc2__tusperapor02_covid-19_pandemi_yonetiminde_turkiye_ornegi. pdf. Accessed Sep 18, 2020.

7. European Centre for Disease Prevention and Control. Coronavirus disease 2019 (COVID-19) in the EU/EEA and the UK - eleventh update: resurgence of cases. Available at: https:// www.ecdc.europa.eu/sites/default/files/documents/covid19-rapid-risk-assessment-20200810.pdf. Accessed Sep 21, 2020.

8. Budak F, Korkmaz Ş. An overall evaluation for the COVID-19 pandemic process: the case of Turkey. Journal of Social Research and Management 2020;1:62-79. [CrossRef]

9. Türk Tabipler Birliği (TTB). COVID-19 2. ay değerlendirme raporu. Available at: https://www.ttb.org.tr/kutuphane/covid19-rapor.pdf. Accessed Sep 21, 2020.

10. Şeker M, Özer A, Tosun Z, Korkut C, Doğrul M. The assessment report on COVID-19 global outbreak. Turkish Academy of Sciences Publications TÜBA; 2020 July. Report No: 39. 
Available at: http://www.tuba.gov.tr/files/yayinlar/raporlar/ T\%C3\%9CBA\%20Assessment\%20Report\%20on\%20COVID-19\%20Global\%200utbreak.pdf. Accessed Sep 20, 2020.

11. Türkiye İçişleri Bakanlığı. 81 il valiliğine şehir giriş-çıkış tedbirleri genelgesi. Available at: https://www.icisleri.gov.tr/81-ilvaliligine-sehir-giris-cikis-tedbirleri-genelgesi. Accessed Sep 20, 2020.

12. Türkiye İçişleri Bakanlığı. COVID-19 kapsamında kamu çalışanlarına yönelik ilave tedbirler; Mart 2020. Available at: https://www.resmigazete.gov.tr/ eskiler/2020/03/20200322M1-1.pdf. Accessed Sep 21, 2020.

13. Google. Human mobility trends. Available at: https://www. google.com/covid19/mobility/. Accessed Sep 28, 2020.

14. Li J, Tartarini F. Changes in air quality during the COVID-19 lockdown in Singapore and associations with human mobility trends. Special issue on COVID-19 aerosol drivers, impacts and mitigation. AAQR 2020;20:1748-58. [CrossRef]

15. Dutheil F, Baker JS and Navel V. COVID-19 as a factor influencing air pollution? Environ Pollut 2020;263(Pt A):114466. [CrossRef]

16. Filonchyk M, Hurynovich V, Yan H, Gusev A, Shpilevskaya N. Impact assessment of COVID19 on variations of SO2, NO2, CO and AOD over East China. AAQR 2020;20(7):1530-40. [CrossRef]

17. Muhammad S, Long X, Salman M. COVID-19 pandemic and environmental pollution: A blessing in disguise? Sci Total Environ 2020;728:138820. [CrossRef]

18. WHO. Air pollution. Available at: https://www.who.int/healthtopics/air-pollution\#tab=tab_1. Accessed Sep 28, 2020.

19. Temiz Hava Hakkı Platformu. Kara rapor. Available at: https:// www.temizhavahakki.com/wp-content/uploads/2020/09/ Kara-Rapor-2020-Son27082020.pdf. Accessed Sep 28, 2020.

20. Türk Mühendis ve Mimarlar Odası (TMMOB). Hava kirliliği raporu. Available at: http://www.cmo.org.tr/resimler/ ekler/3e0f7b1b10bfb89_ek.pdf?tipi=78\&turu=H\&sube=0. Accessed Sep 28, 2020.

21. Wikipedia. Geography of Turkey. Available at: https:// en.wikipedia.org/wiki/Turkey\#Geography. Accessed Sep 28, 2020.

22. Balcı A. A qualitative study on teaching geographical features of Turkey with descriptive activities. Marmara Geographical Review 2012;26:215-58.

23. Türkiye Belediyeler Birliği (TBB). Genel istatistikler. Available at: https://www.tbb.gov.tr/belediyelerimiz/istatistikler/genelistatistikler. Accessed 28 Sep, 2020.

24. Türkiye Çevre ve Şehircilik Bakanlığı. Available at: https://ced. csb.gov.tr/hava-kalitesi-haber-bultenleri-i-82299. Accessed Sep 28, 2020.

25. European Enviromental Agency (EEA). Air quality in Europe, 2019. Available at: https://www.eea.europa.eu/publications/ air-quality-in-europe-2019. Accessed Sep 21, 2020.

26. Karagulian F, Belis CA, Dora CF, Prüss-Ustün AM, Bonjour S, Adair-Rohani $\mathrm{H}$, et al. Contributions to cities' ambient particulate matter (PM): A systematic review of local source contributions at global level. Atmos Environ 2015;120:475-83. [CrossRef]

27. Collivignarelli MC, Abbà A, Bertanza G, Pedrazzani R, Ricciardi P, Carnevale Miino M. Lockdown for CoViD-2019 in Milan: What are the effects on air quality? Sci Total Environ 2020;732:139280. [CrossRef]

28. Health Effects Institute. State of global air 2019. Available at: https://www.stateofglobalair.org/sites/default/files/ soga_2019_report.pdf. Accessed Sep 21, 2020.

29. Bao R, Zhang A. Does lockdown reduce air pollution? Evidence from 44 cities in northern China. Sci Total Environ 2020;731:139052. [CrossRef]

30. Lian X, Huang J, Huang R, Liu C, Wang L, Zhang T. Impact of city lockdown on the air quality of COVID-19-hit of Wuhan city. Sci Total Environ 2020;742:140556. [CrossRef]

31. Otmani A, Benchrif A, Tahri M, Bounakhla M, Chakir EM, El Bouch $M$, et al. Impact of Covid-19 lockdown on PM10, SO2 and NO2 concentrations in Salé City (Morocco). Sci Total Environ 2020;735:139541. [CrossRef]

32. Adams MD. Air pollution in Ontario, Canada during the COVID-19 state of emergency. Sci Total Environ 2020;742:140516.

33. Shehzad K, Sarfraz M, Shah SGM. The impact of COVID-19 as a necessary evil on air pollution in India during the lockdown. Environ Pollut 2020;266(Pt 1):115080. [CrossRef] 